\title{
Algae of economic importance that accumulate cadmium and lead: A review
}

\author{
Priscila O. Souza, ${ }^{1}$ Lizângela R. Ferreira, ${ }^{2}$ Natanael R. X. Pires, ${ }^{2}$ \\ Pedro J. S. Filho, ${ }^{3}$ Fabio A. Duarte, ${ }^{4}$ Claudio M. P. Pereira, ${ }^{1}$ \\ Márcia F. Mesko",2
}

${ }^{1}$ Laboratório de Heterociclos Bioativos e Bioprospecção, Centro de Ciências Químicas, Farmacêuticas e de Alimentos, Universidade Federal de Pelotas, Brazil.

${ }^{2}$ Laboratório de Controle de Contaminantes em Biomateriais, Centro de Ciências Químicas, Farmacêuticas e de Alimentos, Universidade Federal de Pelotas, Brazil. ${ }^{3}$ Laboratório de Análise de Contaminantes Ambientais, Central Analítica, Instituto Federal Sul-Riograndense, Brazil.

${ }^{4}$ Escola de Química e Alimentos, Universidade Federal do Rio Grande, Brazil.
Revista Brasileira de Farmacognosia Brazilian Journal of Pharmacognosy 22(4): 825-837, Jul./Aug. 2012

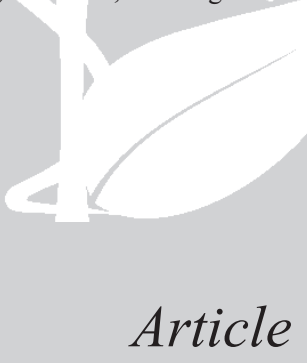

Received 29 Nov 2011

Accepted 29 Jan 2012

Available online 5 Jun 2012

Keywords: bioactive compounds macroalgae metals microalgae secondary metabolites

ISSN 0102-695X http://dx.doi.org/10.1590/S0102 $695 \times 2012005000076$

\section{Introduction}

Environmental contamination by heavy metals is a growing global problem, which is directly related to anthropogenic actions. For this motive, many techniques for environmental remediation of heavy metals are being studied (Ofer et al., 2003; Bayramoğlu et al., 2006; Rai, 2008, 2010; Rawat et al., 2011). Among these techniques, the application of microorganisms has been widely discussed, mainly in view of their capability to remove pollutants from aquatic environments with good efficiency and relatively low cost. In this context, macroalgae and microalgae have special properties that can be used as a powerful technology to reduce environmental contamination.

In particular, intense human activities can result in high metal concentrations in the environment, leading to numerous problems (Phillips, 1995; MacFarlane \& Burchett, 2001). Thus, although low concentrations of some heavy metals are metabolically important to many living organisms, at higher levels they can potentially be toxic (Phillips, 1995; Sunda \& Huntsman, 1998; Pinto et al., 2003a). The pollution generated by heavy metals released from industrial and domestic sources causes serious changes in the aquatic ecosystem, resulting in a loss of biological diversity and the magnification and bioaccumulation of toxic agents in the food chain (He et al., 1998).

Aquatic ecosystems such as rivers, ponds and lakes are mainly affected by pollutants and heavy metals discharged in industrial effluents and represent a potential risk to the health of humans and ecosystems (Rai, 2010). According to Rai (2008), several new technologies have been developed for the removal of heavy metals from wastewaters in a feasible way. Nonetheless, these techniques are often only partially effective and of relatively high cost, which can be an obstacle to large-scale investment. Although trace metals can be toxic to aquatic organisms and can be accumulated by several marine species (Bargagli et al., 1996), recent research has shown that some bacteria, fungi, mussels, fishes and algae have the capability to absorb trace metals and thus have the potential to serve as economically viable biological materials for the reduction of environmental pollution (Lourie et al., 2010).

Some metals and their compounds have been linked to mechanisms of carcinogenicity and metals 
such as cadmium and lead have been widely studied in view of their potential carcinogenicity to humans (Beyersmann \& Hartwig, 2008). In addition, oxidative stress in living organisms can be related to the toxicity of metals, involving an increase in the concentration of reactive oxygen species and/or a reduction in the cellular antioxidant capacity (Pinto et al., 2003a). Oxidative stress can be associated with the inhibition of photosynthesis, of chlorophyll production or of growth in primary producers. These toxic effects can result from exposure to high concentrations of metals or to exposure of lower concentrations for longer periods, reflecting the fact that the toxicity of heavy metals is largely dose-dependent (Baumann et al., 2009). It has been shown that the photosynthesis of some species of macroalgae can be affected by the accumulation of heavy metals (Gledhill et al., 1997; Baumann et al., 2009). Collen et al. (2003) observed that copper $(\mathrm{Cu})$ and cadmium $(\mathrm{Cd})$ induced oxidative stress in Gracilaria tenuistipitata Zhang \& Xia, a red macroalgae in the Gracilariaceae (Rhodophyta) family. Moreover, due to the release of heavy metals and other contaminants into the environment, the difficulty of cultivating Gracilaria has increased (Tonon et al., 2011). Some authors (Pinto et al., 2003a; Torres et al., 2008) have pointed out that exposure to these elements can be a barrier to the growth of many marine organisms, including phytoplankton and macroalgae, which could eventually result in a decrease in biodiversity. Of particular importance is the finding that the lipid composition of algae can be altered by the influence of heavy metals (Vavilin et al., 1998; Rocchetta, et al., 2006). At the same time, it is well known that the oxidation of lipids can occur as a result of oxidative stress, reflecting the production of reactive oxygen/nitrogen species (Pinto et al., 2003b; Leitão et al., 2003). In other experiments (Okamoto et al., 2001; Collen et al., 2003; Rocchetta et al., 2006), it was demonstrated that the levels of polyunsaturated fatty acids (PUFA) are more affected, suffering a greater decrease in the presence of heavy metals. According to Pinto et al. (2011), $\mathrm{Cd}^{2+}$ was more toxic than $\mathrm{Cu}^{2+}$ and greatly reduced the PUFA concentration in G. tenuistipitata. Here it is important to note that Gracilaria is an increasingly important source of secondary metabolites with antimicrobial, antioxidant and antitumoral activities, principally terpenes, several fatty acids and nitrogenous compounds (Cardozo et al., 2007; Boobathy et al., 2010; Zandi et al., 2010; Falcão et al., 2010; Tonon et al., 2011).

The biosorption capacity of the green algae species Spirogyra spp. and Cladophora spp. To accumulate lead $\left(\mathrm{Pb}^{2+}\right)$ and copper $\left(\mathrm{Cu}^{2+}\right)$ from aqueous solutions was evaluated by Lee \& Chang (2011). On the basis of continuous adsorption-desorption experiments, these authors reported that both algal species were excellent biosorbents, with potential for further development. The microalgae Spirogya spp. adsorbed between $10-40 \mathrm{mg} \mathrm{g}^{-1}$ of $\mathrm{Pb}^{2+}$ and between $45-90 \mathrm{mg}$ $\mathrm{g}^{-1}$ of $\mathrm{Cu}^{2+}$ from aqueous solutions containing different concentrations of $\mathrm{Pb}^{2+}$ and $\mathrm{Cu}^{2+}$. By comparison, the algae Cladophora spp. adsorbed between 5-10 $\mathrm{mg} \mathrm{g}^{-1}$ of $\mathrm{Pb}^{2+}$ and between $30-45 \mathrm{mg} \mathrm{g}^{-1}$ of $\mathrm{Cu}^{2+}$.

Several studies have explored the metal binding properties of different biosorbents such as fungi, yeasts, bacteria and algae (Volesky \& Holan, 1995; Kapoor \& Viraraghavan, 1995). Numerous studies have employed macroalgae and microalgae for the biosorption of metals and the ability of certain species of macroalgae to accumulate and tolerate high levels of metals has been demonstrated. Hence, algae represent an effective, economically viable and environmentally friendly (Yu et al., 1999) alternative for the bioremediation of heavy metals, especially cadmium and lead, the two metals that are subject of the present review.

\section{Bioremediation}

Heavy metals discharged into the environment tend to persist indefinitely, sometimes accumulating in living organism via food chain, and are thus considered to represent a potentially serious environmental threat (Kuppusamy et al., 2004). The most effective and least expensive methods for the remediation of waters contaminated by heavy metals have been the focus of much research in recent decades, with the objective of reducing the risk to public health caused by the presence of these wastewater contaminants (Kumar et al., 2009). Compared to conventional treatment methods, biosorption stands out because of the following advantages: high efficiency of removal of metals from dilute solutions; low cost; and minimization of chemical and/or biological sewage. Moreover, it does not require addition of nutrients or regeneration of the biosorbent and makes it possible to recover the metals (Kratochvil \& Volesky, 1998). According to Goyal et al. (2003), the biosorption of metals can be performed by many different microorganisms, including bacteria, yeast, fungi and algae. Schiewer \& Patil (1997) reported that the efficiency of different biosorbents for the removal of heavy metals can depend on the $\mathrm{pH}$ of the solution.

Due to stricter government regulations, there has been a growing interest in cost-effective remediation technologies (Davis et al., 2003). In this context, bioremediation of polluted areas and wastewater can be an economically viable alternative, especially when the sorbent can be recycled and the heavy metals recovered for resale. Remediation of heavy metals encourages environmental awareness and ameliorates the effects of pollution (Salt et al., 1995). Bioremediation uses naturally occurring biomass as the substrate for 
chelation of the metal ions, either passively or through non-metabolically mediated processes (Baumann et al., 2009).

Given their abundance in various environmental systems, their adaptability to different environmental conditions (Rajfur et al., 2010) and their ability to accumulate large amounts of heavy metals such as cadmium, lead, zinc, copper, chromium, and manganese (Anastasakis et al., 2011), algae appear to be the most appropriate microorganism for monitoring pollution of water resources by heavy metals (Wallenstein et al., 2009; Rajamani et al., 2007). Indeed, algae have been used for over 40 years for the treatment of wastewater, the first application being described by Oswald \& Gotaas (1957). More recently, John (2000; Rawat et al., 2011) introduced the term phycoremediation to refer to remediation by algae. In this context, it is important to emphasize that phycoremediation has several applications in addition to the removal of metals. These include the: (i) removal of nutrients from municipal wastewater and from effluents rich in organic matter; (ii) removal of nutrients and xenobiotic compounds with the help of biosorbents based on algae; (iii) treatment of acidic wastewater and metals; (iv) sequestration of $\mathrm{CO}_{2}$; (v) transformation and degradation of xenobiotics; and (vi) detection of toxic compounds with algae-based biosensors (Rawat et al., 2011).

Many intrinsic and extrinsic factors can influence the accumulation of metals by algae, such as cellular activity, exposure time, chelating species, and environmental factors such as $\mathrm{pH}$, salinity, organic matter, and temperature (Runcie \& Riddle, 2004). Furthermore, structural differences between species influence their absorption capacity (Favero \& Frigo, 2002). For the macroalgae Durvillaea antarctica (Chamisso) Hariot, Runcie \& Riddle (2004) observed a low metal content that could be ascribed to the low availability of the metals in the surrounding waters.

Recently, macroalgae have been increasingly used as a tool for monitoring marine environments contaminated by heavy metals (Daka et al., 2003; Stengel et al., 2004; Daby, 2006, Baumann et al., 2009; Kumar et al., 2009; Tonon et al., 2011). Many macroalgae are able to accumulate high levels of trace metals, which are sometimes larger than those found in water samples from the same site (Cardwell et al., 2002; Salgado et al., 2006).

In order to determine the heavy metals present in environmental samples, analytical techniques such as atomic absorption spectrometry (AAS) (Carrilho et al., 2003; Zhang \& O'Connor, 2005) have been widely used due to the relatively low cost. However, inductively coupled plasma mass spectrometry (ICPMS) and inductively coupled plasma optical emission spectrometry (ICP OES) have been increasingly used for metal determination in view of their much lower limits of detection and the capability of multielement detection when coupled with suitable sample preparation procedures (Mesko et al., 2011; Soares et al., 2012).

In the remainder of this review, we shall concentrate on two especially toxic heavy metals, cadmium and lead, and their biosorption by micro- and macroalgae.

\section{Cadmium}

Cadmium stands out among the heavy metals because it is relatively easily removed from waste streams, primarily due to its ability to form stable complexes with several different ligands (Ofer et al., 2003). The presence of cadmium in natural waters is extremely undesirable since it is both toxic and a nonessential element for most living organisms (Leborans \& Novillo, 1996; Farias et al., 2002).

In a recent research, Tonon et al. (2011) evaluated the absorption of cadmium $(\mathrm{Cd})$ and copper (Cu) by three species of Gracilaria: G. tenuistipata Zhang \& Xia cultivated in the laboratory and exposed to the metal and G. birdiae Plastino \& Oliveira and $G$. domingensis (Kützing) collected in their natural environments. G. tenuistipitata bioaccumulated higher concentrations of $\mathrm{Cu}$ than $\mathrm{Cd}$, showing that this macroalgae is a metal bio-accumulating organism; the biological function of the accumulated $\mathrm{Cd}$, if any, is currently unknown.

Stohs \& Bagchi (1995) suggested that Cd ions might displace zinc and iron from proteins. This could potentially have deleterious consequences for seaweed growth because the liberation of iron ions might induce the Fenton reaction, producing reactive oxygen species (ROS) and total oxidative stress. In land plants, $\mathrm{Cd}$ competes for divalent ion carriers and can be transported with protons and type P ATPases. According to Guerinot (2000), the ability to compete for essential metal carriers is particularly important for cadmium $(\mathrm{Cd})$, mercury $(\mathrm{Hg})$ and lead $(\mathrm{Pb})$. Baumann et al. (2009) evaluated the Cd concentration in seven algal species and noted that $10 \mathrm{mmol} \mathrm{L}^{-1}$ cadmium ion led to the greatest increase in $\mathrm{Cd}$ accumulation. The macroalgae Palmaria palmata (Linnaeus) Kuntze had the highest concentrations of $\mathrm{Cd}$ and Ascophyllum nodosum (Linnaeus) the lowest. Despite the fact that $P$. palmata accumulated the highest amounts of $\mathrm{Cd}$ and showed a significant reduction in fluorescence, no correlation was found between $\mathrm{Cd}$ accumulation and its toxicity. Küpper et al. (1996, 1998) demonstrated that photosynthesis can be affected by exposure to $\mathrm{Cd}$ and $\mathrm{Zn}$, which can replace the $\mathrm{Mg}^{2+}$ in the chlorophyll molecule, affecting its light-harvesting ability. 


\section{Lead}

Lead is a more pernicious contaminant in aquatic environments and is rapidly accumulated by organisms (Ribeiro et al., 2010). Moreover, it is able to bind strongly to amino acids, enzymes, DNA and RNA and can induce the production of reactive oxygen species (ROS) like the superoxide radical and hydrogen peroxide that can cause severe oxidative damage to plant cells (e.g., by increasing membrane lipid peroxidation and permeability) (Apel \& Hirt, 2004). Lead can inhibit the synthesis of chlorophyll because it changes the absorption of essential elements such as Mg and Fe (Sunda \& Huntsman, 1998).

The biological functions of lead in algae are unknown (Pawlik-Skowronska, 2000), but lead is known to have adverse effects on microalgal morphology, growth and photosynthesis when present at high concentrations (Pawlik-Skowronska, 2002).

Baumann et al. (2009) showed that for brown algae there was significant variation in $\mathrm{Pb}$ concentrations for all seven species of algae examined. Lead proved to be less toxic than the other five metals evaluated, but was accumulated to a greater extent by all seven algae tested than the other metals. Moreover, none of the treatments with lead affected the fluorescence yield of either species. According to Miles et al. (1972), lead affects light absorption by PSI and PSII and the chloroplast coupling factor. However, Baumann et al. (2009) demonstrated that lead was the only metal out of five tested that did not reduce chlorophyll fluorescence in the species evaluated. The results indicaated that macroalgae, especially Ulva intestinalis Linnaeus, are promising organisms for the bioremediation of waters contaminated by lead, because of their apparent tolerance to $\mathrm{Pb}$ and their ability to accumulate lead at high rates.

\section{Applications of algae in the pharmaceutical industry and in environmental remediation}

The pharmaceutical industry has shown great interest in the use of algae as a source of biochemically active substances (Burja et al., 2001, Singh et al., 2005, Blunt et al., 2005, Guaratini et al, 2005; Cardozo et al., 2008; Cardozo et al., 2009; Guaratini et al., 2009). The fact that algae may produce chemical prototypes of new therapeutic agents has stimulated bioprospecting for new algal secondary metabolites and the synthetic modification of compounds with potential pharmaceutical applications (Cardozo et al., 2007). In addition to novel biologically active substances, algae also provide compounds essential to human nutrition (Burja et al., 2001; Gressler et al., 2010).

Cardozo et al. $(2006 ; 2007)$ described the main substances biosynthesized by algae with a potential economic impact on nutrition, public health and the pharmaceutical industry. The diversity of compounds synthesized by marine algae via a variety of metabolic pathways is the result of the defense strategies that they have developed in order to survive in a highly competitive environment. Hence, many of these secondary metabolites are chemically distinct from those found in terrestrial organisms (Burja et al., 2001; Singh et al., 2005; Blunt et al., 2005; Carignan et al., 2009; Wijesinghe \& Jeon, 2011). According to Kamatou et al. (2008), the presence of these compounds may help explain some of the traditional uses of medicinal plants.

Algae are ecologically important because they occupy the base of the food chain in aquatic ecosystems and produce half of the $\mathrm{O}_{2}$ and the majority of the dimethylsulfide released into the atmosphere. In addition, algae are the main source of food for bivalve mollusks in all stages of growth, for zooplankton (rotifers, copepods and brine shrimp) and for the larval stages of crustaceans and some species of fish (Cardozo et al., 2007) .

The quality of the food transferred to the higher trophic levels of the food chain is determined by the chemical composition of algae (such as fatty acids, sterols, amino acids, sugars, minerals and vitamins) (Brown \& Miller, 1992; Di Mascio et al., 1995; Guaratini et al., 2007; Dhargalkar \& Verlecar, 2009). The nutritional value of algal species depends on several characteristics such as size, shape, digestibility and toxicity (Cardozo et al., 2007). The Chinese, Japanese and Korean diet includes the consumption of several species of red and brown algae (Dawczynski et al., 2007). In addition to this traditional use in the East, people in many other parts of the world also consume or come into contact with algae-derived products used as additives in manufactured food products and processed meat and fruit or in everyday materials such as toothpaste, paint, solid air fresheners and cosmetics (Gressler et al., 2009; 2011).

Algal biomass can be effectively applied in bioremediation because the proteins and polysaccharides of their cell walls can contain anionic carboxylate, sulfate or phosphate groups, which are optimal binding sites for metals (Farias et al., 2002). Several studies have shown that it is possible to enhance the accumulation of metals by algal biomass. Thus, Kumar \& Gaur (2011) observed that pretreatment with $\mathrm{CaCl}_{2}$ generated new sites for metal ion binding by inducing cross-linking between the polymer chains of the exopolysaccharides present in the biomass. Mehta et al. (2002) and Kalyani et al. (2004) found that pre-treatment with $\mathrm{HCl}$ increased the metal binding capacity of biomass (by 39 or $70 \%$, respectively), presumably be removing cationic species that were bound to the anionic functional groups, 
making them available for binding of additional metal ions. An improvement in the biosorption capacity for metal ions could also be induced by an alkaline pretreatment, reflecting increased deprotonation of the acidic functional groups of the biomass (Sampedro et al.. 1995; Mehta \& Gaur, 2001; Nagase et al., 2005; Singh et al., 2007, 2008).

The performance of treatment systems using algal biomass can be reduced by the presence of chelating agents, such as fulvic acid, that can compete with the anionic groups of algal biomass for binding of metal ions (Pascucci \& Kowalak, 1999). In addition, there is a decrease in the percentage of metal removed at higher metal concentrations (Pujari \& Chandra, 2000) due to the saturation of the available metal binding sites (Dönmez \& Aksu, 2002). In this case, the use of a greater amount of biomass may not enhance the overall extent of metal ion binding if the metal ions that initially bind to a dense layer of cells create a screening effect (Zulkali et al., 2006).

\section{Macroalgae}

Seaweeds represent a significant portion of global biodiversity. They constitute a large and diverse group of organisms that play vital ecological roles in marine communities and can be classified into three categories according to their pigmentation: brown, red and green algae (Wijesinghe \& Jeon, 2011).

Seaweeds are a potentially renewable marine resource and are known to be extremely rich in bioactive compounds (Chandini et al., 2008; Kladi et al. 2004) with novel biological activities (Kashman \& Rudi, 2004; Plaza et al., 2008). The brown seaweeds or Phaeophyceae are noted for producing a range of active components, including unique secondary metabolites such as phlorotannins (Wijesinghe \& Jeon, 2011). In addition, several components of brown algae have been explored for their antioxidant, antiallergic, antiinflammatory, antiwrinkling and whitening properties.

Compared to other types of biomass, brown algae showed the highest metal binding capacity, making them particularly attractive for the bioremediation of toxic heavy metals (Ofer et al., 2003). According to Davis et al. (2003), the linear polysaccharides known as alginate, which are present in gel form in the stem of algae, are responsible for the biosorption of heavy metals by these algae. Moreover, they noted that the orders Laminariales and Fucales are probably the largest seaweeds, and are the most abundant and widespread, enhancing their potential for cost-effective application in bioremediation. Macroalgae are usually sessile and accumulate metals over time, so that differences in the metal content of macroalgae depend on whether they are located near and far from sources of pollution and can be used to infer the source of metal contamination (Runcie \& Riddle, 2004). However, as pointed out by Singh et al. (2007), this application does have its limitations because of the confinement of seaweeds to coastal areas and the difficulty of collecting them during the metal sorption process.

In a comparative study reported by Kumar et al. (2009), the ability to accumulate cadmium and lead was evaluated for five green marine macroalgae by employing initial metal concentrations in the range of 20 to $80 \mathrm{mg} \mathrm{L}^{-1}$ and different contact periods. The $\mathrm{Pb}$ uptake values for Cladophora fasicularis (Mertens ex C. Agardh) Kützing ranged from 5.68 to $33.53 \mathrm{mg} \mathrm{g}^{-1}$, while Cd uptake values ranged from 4.08 to $18.78 \mathrm{mg}$ $\mathrm{g}^{-1}$. The Cd uptake values for Ulva lactuca varied from 3.89 to $7.84 \mathrm{mg} \mathrm{g}^{-1}$ and those for $\mathrm{Pb}$ uptake from 6.19 to $25.07 \mathrm{mg} \mathrm{g}^{-1}$. For Chaetomorpha $\mathrm{sp}$, the $\mathrm{Pb}$ uptakes were between 7.52 and $35.08 \mathrm{mg} \mathrm{g}^{-1}$ and the Cd uptakes between 7.98 and $31.55 \mathrm{mg} \mathrm{g}^{-1}$. Caulerpa sertularioides (S.G.Gmelin) M.A.Howe showed Cd uptake values in the range of 1.19 to $20.51 \mathrm{mg} \mathrm{g}^{-1}$ and $\mathrm{Pb}$ values in the range of 6.03 to $21.58 \mathrm{mg} \mathrm{g}^{-1}$. Valoniopsis pachynema (G. Martens) Borgesen had Cd uptakes in the range of 7.69 to $17.31 \mathrm{mg} \mathrm{g}^{-1}$ and $\mathrm{Pb}$ uptakes from 6.42 to 37.71 $\mathrm{mg} \mathrm{g}^{-1}$. The efficiency of cadmiun absorption varied in the order: Chaetomorpha sp. $>C$. sertularioides $>C$. fasicularis $>V$. pachynema $>U$. lactuca; for lead, the corresponding order was: $V$. pachynema $>$ Chaetomorpha sp. $>C$. fasicularis $>$ U. lactuca $>C$. sertularioides. During the experimental exposure of the seaweeds to these two heavy metals, the concentration of free metal ion decreased significantly, demonstrating that seaweeds can be excellent biosorbents.

Figueira et al. (2000) used several species of the brown seaweeds Durvillaea sp., Laminaria sp., Ecklonia sp. and Homosira sp., pre-saturated with $\mathrm{Ca}$, $\mathrm{Mg}$ and $\mathrm{K}$, and Hashim \& Chu (2004) examined seven species of brown, green and red seaweeds in order to assess their ability to remove cadmium from aqueous medium.

Gosavi et al. (2004) demonstrated that four genera of macroalgae (Ulva sp., Enteromorpha sp., Chaetomorpha sp. and Cladophora sp.) accumulated significant amounts of $\mathrm{Fe}, \mathrm{Al}, \mathrm{Zn}, \mathrm{Cd}, \mathrm{Cu}, \mathrm{As}$ and $\mathrm{Pb}$, noting that cadmium was absorbed better by Cladophora sp. (1.6 $\left.\pm 0.3 \mathrm{mg} \mathrm{g}^{-1}\right)$, while Chaetomorpha sp. and Enteromorpha sp. absorbed lead better. According to Thomas et al. (2003), brown algae are the most effective and promising substrates for $\mathrm{Pb}$ accumulation. Farias et al. (2002) evaluated eleven species of macroalgae from the Antarctica; the highest levels of trace metals were found in Monostroma hariotii Gain and Phaeurus antarcticus Skottsberg. However, M. hariotii was not able to accumulate $\mathrm{As}, \mathrm{Cd}$ and $\mathrm{Pb}$, which are relevant 
because of their potential toxicity to living organisms. Table 1 provides an annotated compendium of literature reports published in the last decade on the application of macroalgae for the biosorption of metals.

\section{Microalgae}

As an important biological resource with multiple applications, microalgae have attracted great interest (Sigaud-Kutner et al., 2002; Pinto et al., 2003b; Rawat et al., 2011). At the same time that they bioremediate wastewater, they provide biomass that can be used to sequester carbon dioxide (Olguin, 2003; Munoz \& Guieyesse, 2006; Briens et al., 2008; Singh \& $\mathrm{Gu}, 2010$ ) and to produce biofuels (methane, ethanol, hydrogen, butanol etc.). Particularly advantageous features of microalgae as a source of biomass for the production of biodiesel include a high growth rate and short regeneration time, a high lipid content, the minimal requirement of land area, and the use of wastewater as the source of nutrients for growth, without the use of chemicals such as herbicides and pesticides (Rawat et al., 2011). The main disadvantage is the difficulty of separation of the microalgae, which are usually unicellular, from their suspensions (Moreno-Garrido, 2008).

The growth of microalgae can be indicative of water pollution since they typically respond to ions and toxins (Rawat et al., 2011). Thus, the remediation of wastewater by using microalgae is an environmentally friendly process that does not generate secondary pollutants and yields biomass that can be reused, enabling efficient recycling of nutrients (Munoz \& Guieyesse, 2006). Besides their use in bioremediation and biofuel production, microalgae can also be used as additives in animal feed and for the extraction of added-value products such as carotenoids and other biomolecules (Rawat et al., 2011; Hobuss et al., 2011; Soares et al., 2012).

The release of municipal and industrial wastewater into bodies of water results in serious environmental changes (Arora \& Saxena, 2005; Bashan \& Bashan, 2010). Eutrophication, induced by a richness of organic matter and of inorganic chemicals such as phosphates and nitrate, can be particularly problematic (Olguin, 2003; Godos et al., 2009; Bashan \& Bashan, 2010). Eutrophication can be avoided with microalgae because they use the wastewater as a food source for their growth (Rawat et al., 2011) and the accumulation of biomass (Munoz \& Guieysse, 2006; Pittman et al., 2011). A wide range of microalgae, such as Chlorella sp., Scenedesmus sp., Phormidium sp., Botryococcus sp., Clamydomonas sp. and Spirulina sp. (Olguin, 2003; Chinnasamy et al., 2010; Kong et al., 2010; Wang et al., 2010), can be effectively employed to treat domestic wastewater. Using a consortium of 15 isolated native algae, Chinnasamy et al. (2010) found $>96 \%$ removal of nutrients from treated wastewater.

The rapid decline in the levels of metals, nitrates and phosphates in wastewater upon microalgal treatment (Wang et al., 2010), demonstrates the efficiency of microalgae for the removal of metals and nutrients, while meeting the stringent requirements of international standards (Rawat et al., 2011).

Microalgae are a source of peptides with the special ability to bind heavy metals (Perales-Vela, 2006). These proteins form organometallic complexes that partition into the vacuoles to facilitate control of the cytoplasmic concentrations of metal ions, thereby preventing or neutralizing their potential toxic effects (Cobbett \& Goldsbrough, 2002). Prokaryotes use a mechanism that is different from that of eukaryotes, which use the consumption of ATP to drive the efflux of heavy metals or enzymatic changes in metal speciation for detoxification (Nies, 1999). These peptides can be classified into two categories: (Robinson, 1989; Rauser, 1990; Steffens, 1990; Thiele, 1992):

1. Short-chain polypeptides, synthesized enzymatically and called phytochelatins or class III metallothioneins, are found in higher plants, algae and certain fungi;

2. Proteins encoded by genes, which include the class II metallothioneins (found in cyanobacteria, algae and higher plants) and class I metallothioneins (found in most vertebrates, in Neurospora and Agaricus bisporus, but with no records so far in algae).

Initially, when the short-chain polysaccharides were discovered they were named phytochelatins (PC) because they were isolated from higher plants, explaining the prefix "phyto", and had the ability to chelate cadmium ions (Grill et al., 1985; Steffens, 1990). However, the class II metallothioneins proved to be effective in plant responses to stress by heavy metals and the name of the PC was changed to class III metallothioneins (Mt III) (Rauser, 1990). Howe \& Merchant (1992) showed that the microalgae Chlamydomonas reinhardtii P.A. Dangeard could sequester about $70 \%$ of the cadmium present in the cytosol by the action of Mt III.

In a study by Avilés et al. (2003) with the flagellated protist Euglena gracilis exposed to cadmium, $79 \%$ of the metal was accumulated in mitochondria and there was an increase in the concentration of Cys and glutathione in cells treated with cadmium. In addition, $17 \%$ of the total Mt III found in the treated cells was concentrated in the mitochondria. According to MendozaCózatl et al. (2004), the presence of Mt III and $\mathrm{Cd}^{2+}$ in chloroplasts and mitochondria of Euglena may be the result of the following processes:

(1) the Mt III are synthesized and sequester $\mathrm{Cd}^{2+}$ in the cytosol; the Cd-Mt III complexes are then 
subsequently transported inside the chloroplast and mitochondria;

(2) the Mt III are synthesized in these two organelles and bind $\mathrm{Cd}^{2+}$ transported as free ions, forming the HMW complexes;

(3) both processes co-exist and the Mt III are synthesized in the three cellular compartments.

Microalgae are often grown in two commercial systems: open raceway ponds and closed photobioreactors (Hollnagel et a;, 1996; Chisti, 2007; Munoz \& Guieyesse, 2006; Chinnasamy et al., 2010). The former system is inexpensive and allows the removal of nutrients from domestic wastewater, while photobioreactors, despite increased productivity, and not feasible on a large scale for phycoremediation due to economic limitations (Chinnasamy et al., 2010). The separation of algal biomass can be accomplished by methods such as centrifugation, flocculation, sedimentation, microfiltration and combinations of these (Grima et al., 2003; Munoz \& Guieyesse, 2006; Danquah et al., 2009; Mutanda et al., 2011). Hobuss et al. (2011) reported a preliminary study of biodiesel production by the microalgae Chlorella vulgaris Beijerinck cultivated in a photobioreactor; the biodiesel was obtained in a significantly shorter time and with good lipid productivity.

The use of high rate algal ponds (HRAP) for the treatment of wastewater results in the production of large amounts of algal biomass, which can be converted into biofuels in many ways, including anaerobic digestion to give biogas, transesterification of lipids to obtain biodiesel, fermentation of carbohydrates into bioethanol and high temperature conversion to bio-crude oil (Mesple et al., 1996; Munoz \& Guieyesse, 2006; Park et al., 2011). Moreover, HRAP are an effective system for phytoremediation, replacing conventional tertiary treatment nutrient removal, which has a cost four times higher than that of conventional primary treatment (Mesple et al., 1996; Olguin et al., 2004; Moreno-Garrido, 2008; Godos et al., 2009; Garcia et al., 2009). The main advantages of this treatment are that microalgal photosynthesis releases oxygen and there is no need for mechanical aeration because the microbial degradation of organic matter is heterotrophic.

Considering the ability of microalgae to degrade organic pollutants, dangerous species of Chlorella sp., Ankistrodesmus sp. and Scenedesmus sp. have demonstrated success in the treatment of refinery wastewater and wastewater from paper mills (Pinto et al., 2002). Cerniglia et al. (1979, 1980) evaluated the ability of algae to biodegrade the organic pollutants present in municipal waste by stimulating cell growth in the presence of pollutants; they found that cyanobacteria and eukaryotic microalgae biotransformed naphthalene into four main non-toxic metabolites (1-naphthol, 4-hydroxy-4-tetralone, cis-dihydronaphthalene diol and trans-dihydronaphthalene diol).

Inthorn et al. (2002) showed that green microalgae (C. vulgaris, Scenedesmus sp. Chlorococcum sp. and

Table 1. Applications of seaweeds for the biosorption of metals.

\begin{tabular}{|c|c|c|c|}
\hline Seaweeds & Elements & Remarks & References \\
\hline $\begin{array}{l}\text { Gracilaria tenuistipata Zhang \& Xia, G.birdiae } \\
\text { Plastino \& Oliveira, G.domingensis (Kützing) }\end{array}$ & $\mathrm{Cd}$ and $\mathrm{Cu}$ & $\begin{array}{l}\text { G. tenuistipitata was able to bioaccumulate higher } \\
\text { concentrations of } \mathrm{Cu}\left(0.13 \pm 0.03 \mu \mathrm{g} \mathrm{g}^{-1}\right) \text { than } \mathrm{Cd} \\
\left(<0.01 \mu \mathrm{g} \mathrm{g}^{-1}\right)\end{array}$ & $\begin{array}{l}\text { Tonon et al., } \\
2011\end{array}$ \\
\hline $\begin{array}{l}\text { Ascophyllum nodosum (Linnaeus) Le Jolis, Fucus } \\
\text { vesiculosus Linnaeus, Ulva intestinalis Linnaeus, } \\
\text { Cladophora rupestris (Linnaeus) Kützing, Chondrus } \\
\text { crispus Stackhouse, Palmaria palmata (Linnaeus) } \\
\text { Kuntze, Polysiphonia lanosa (Linnaeus) Tandy }\end{array}$ & $\mathrm{Cd}$ and $\mathrm{Pb}$ & $\begin{array}{l}\text { P. palmata had the highest concentrations of } \mathrm{Cd} \\
\text { and } A \text {. nodosum the lowest. No correlation was } \\
\text { found between } \mathrm{Cd} \text { accumulation and its toxicity. } U \text {. } \\
\text { intestinalis had apparent tolerance to } \mathrm{Pb} \text {, as well as } \\
\text { the ability to accumulate it at high rates. }\end{array}$ & $\begin{array}{l}\text { Baumann et al., } \\
2009\end{array}$ \\
\hline $\begin{array}{l}\text { Chaetomorpha sp., Caulerpa sertularioides } \\
\text { (S.G.Gmelin) M.A.Howe, Cladophora fasicularis } \\
\text { (Mertens ex C. Agardh) Kützing, Valoniopsis } \\
\text { pachynema (G. Martens) Borgesen, Ulva lactuca }\end{array}$ & $\mathrm{Cd}$ and $\mathrm{Pb}$ & $\begin{array}{l}\text { Chaetomorpha sp. accumulated more } \mathrm{Cd} \text { than } \mathrm{U} \text {. } \\
\text { lactuca; and } V \text {. pachynema amassed more } \mathrm{Pb} \text { than } \\
\text { C. sertularioides. }\end{array}$ & $\begin{array}{l}\text { Kumar et al., } \\
2009\end{array}$ \\
\hline $\begin{array}{l}\text { Ulva sp., Enteromorpha sp., Chaetomorpha sp., } \\
\text { Cladophora } \mathrm{sp.}\end{array}$ & $\begin{array}{l}\mathrm{Fe}, \mathrm{Al}, \mathrm{Zn}, \mathrm{Cd}, \\
\mathrm{Cu}, \mathrm{As} \text { and } \mathrm{Pb}\end{array}$ & $\begin{array}{l}\text { Cd was more absorbed by Cladophora } \mathrm{sp} \text {. } \\
\left(1.6 \pm 0.3 \mathrm{mg} \mathrm{g}^{-1}\right) \text {, while the Chaetomorpha } \mathrm{sp} \text {. and } \\
\text { Enteromorpha } \mathrm{sp} \text {. absorbed more } \mathrm{Pb}\end{array}$ & $\begin{array}{l}\text { Gosavi et al. } \\
\qquad(2004)\end{array}$ \\
\hline $\begin{array}{l}\text { Ascoseira mirabilis Skottsberg, Palmaria decipiens } \\
\text { (Reinsch) R.W.Ricker, Desmarestia anceps Montagne, } \\
\text { Monostroma hariotti Gain, Adenocystis utricularis } \\
\text { (Bory de Saint-Vincent) Skottsberg, Desmarestia } \\
\text { antarctica R.L.Moe \& P.C. Silva, Himantothallus } \\
\text { grandifolius (A.Gepp \& E.S.Gepp) Zinova, Iridaea } \\
\text { cordata (Turner) Bory de Saint-Vicent, Phaeurus } \\
\text { antarcticus Skottsberg, Georgiella confluens (Reinsch) } \\
\text { Kylin, Myriogramme mangini (Gain) Skottsberg }\end{array}$ & $\begin{array}{l}\mathrm{As}, \mathrm{Cd}, \mathrm{Co}, \mathrm{Cr} \text {, } \\
\mathrm{Cu}, \mathrm{Fe}, \mathrm{Mn}, \\
\mathrm{Mo}, \mathrm{Ni}, \mathrm{Pb}, \mathrm{Se}, \\
\mathrm{Sr}, \mathrm{V} \text {, and } \mathrm{Zn}\end{array}$ & $\begin{array}{l}\text { Highest levels of trace metals were found in } M \text {. } \\
\text { hariotii and } P \text {. antarcticus; however, } M \text {. hariotii } \\
\text { was not able to accumulate } \mathrm{As}, \mathrm{Cd} \text { and } \mathrm{Pb} \text {, which } \\
\text { are relevant given their toxicity potential for living } \\
\text { organisms. }\end{array}$ & $\begin{array}{l}\text { Farias et al., } \\
2002\end{array}$ \\
\hline
\end{tabular}


Table 2. Applications of microalgae for the biosorption of metals

\begin{tabular}{|c|c|c|c|}
\hline Microalgae & Elements & Remarks & References \\
\hline Oscillatoria sp. and Phormidium sp. & $\begin{array}{l}\mathrm{Cu}(\mathrm{II}), \mathrm{Cd}(\mathrm{II}) \\
\text { and } \mathrm{Pb}(\mathrm{II})\end{array}$ & $\begin{array}{l}\text { Phormidium sp. and Oscillatoria sp. dominated } \\
\text { mats showed a strong propensity to take up } \mathrm{Pb} \\
\text { (II), } \mathrm{Cu} \text { (II) and } \mathrm{Cd} \text { (II) from solutions with } \mathrm{pH} \\
\text { 4-6. The test mats have great potential for use in } \\
\text { metal removal from wastewaters because of their } \\
\text { widespread distribution, immobility, rapid sorption } \\
\text { and desorption, good mechanical strength and } \\
\text { possibility of reuse during successive sorption- } \\
\text { desorption cycles. }\end{array}$ & $\begin{array}{c}\text { Kumar \& Gaur, } \\
2011\end{array}$ \\
\hline Microcystis novacekii (Komarek) Compère & $\mathrm{Pb}$ & $\begin{array}{l}\text { The microalgae had a maximum capacity of } \\
\text { sorption of } 70 \mathrm{mg} \mathrm{g}^{-1} \text {, removing lead from water. }\end{array}$ & $\begin{array}{l}\text { Ribeiro et al., } \\
2010\end{array}$ \\
\hline Chlamydomonas reinhardtii P.A. Dangeard & $\begin{array}{l}\mathrm{Hg}(\mathrm{II}), \mathrm{Cd}(\mathrm{II}) \\
\quad \text { and } \mathrm{Pb}(\mathrm{II})\end{array}$ & $\begin{array}{l}\text { Ca-alginate beads and immobilized biomass of } \\
\text { microalgae were shown to be agents of biosorption } \\
\text { for the removal of ions from aqueous medium. }\end{array}$ & $\begin{array}{l}\text { Bayramoğlu et } \\
\text { al., } 2006\end{array}$ \\
\hline $\begin{array}{l}\text { C. vulgaris, Scenedesmus sp. Chlorococcum sp. } \\
\text { and Fischerella sp. (green microalgae) and Lyngbya } \\
\text { spiralis Geitler, Tolypothrix tenuis Kützing, Stigonema } \\
\text { sp. and Phormidium molle (Kützing) Gomont } \\
\text { (cyanobacteria) }\end{array}$ & $\begin{array}{l}\mathrm{Pb}(\mathrm{II}), \mathrm{Cd}(\mathrm{II}) \\
\text { and } \mathrm{Hg} \text { (II) }\end{array}$ & $\begin{array}{l}\text { Green microalgae and cyanobacteria removed ions } \\
\text { efficiently. }\end{array}$ & $\begin{array}{l}\text { Inthorn et al., } \\
2002\end{array}$ \\
\hline Chlamydomonas reinhardtii P.A. Dangeard & $\mathrm{Cd}$ & $\begin{array}{l}\text { The sorption of Cd by C.reinhardtii was dominated } \\
\text { by carboxyl groups and this microalgae is a } \\
\text { promising sorbent for removal of Cd from } \\
\text { contaminated waters. }\end{array}$ & $\begin{array}{l}\text { Adhiya et al., } \\
\quad 2002\end{array}$ \\
\hline Chlamydomonas reinhardtii P.A. Dangeard & $\begin{array}{l}\mathrm{Cd}, \mathrm{Co}, \mathrm{Cu} \\
\text { and } \mathrm{Ni}\end{array}$ & $\begin{array}{l}\text { The metals, in increasing order of affinity for the } \\
\text { cell wall, are } \mathrm{Ni}, \mathrm{Co}, \mathrm{Cd} \text { and } \mathrm{Cu} \text {. }\end{array}$ & $\begin{array}{c}\text { Macfie \& } \\
\text { Welbourn, } 2000\end{array}$ \\
\hline Chlamydomonas reinhardtii P.A. Dangeard & $\mathrm{Cd}$ & $\begin{array}{l}\text { The microalgae sequestered about } 70 \% \text { of the } \mathrm{Cd} \\
\text { present in the cytosol by the action of Mt III }\end{array}$ & $\begin{array}{c}\text { Howe \& } \\
\text { Merchant, } 1992\end{array}$ \\
\hline
\end{tabular}

Fischerella sp.) and cyanobacteria (Lyngbya spiralis Geitler, Tolypothrix tenuis Kützing, Stigonema sp. and Phormidium molle (Kützing) Gomont) efficiently removed $\mathrm{Pb}$ (II), Cd (II) and $\mathrm{Hg}$ (II) ions. Recently, there has been a growing use of the unicellular microalgae $C$. reinhardtii in bioremediation (Macfie \& Welbourn, 2000; Adhiya et al., 2002). Bayramoğlu et al. (2006) isolated wild-type $C$. reinhardtii from a polluted part of the Kizilirmak river, taking advantage of the fact that species growing in polluted areas have a higher resistance and ability to accumulate heavy metals. They showed that Ca-alginate bead with immobilized biomass of the microalgae were biosorbents capable of removing $\mathrm{Hg}$ (II), $\mathrm{Cd}$ (II) and $\mathrm{Pb}$ (II) ions from aqueous media.

The cyanobacterium Microcystis novacekii (Komarek) Compère, present in many tropical countries, is found in eutrophic and polluted environments (Singh, 1998), indicating that this species may be resistant to exposure to toxic agents, including heavy metals (Pradhan et al., 2007). According to Ribeiro et al. (2010), the biomass of $M$. novacekii had a maximum sorption capacity of $70 \mathrm{mg} \mathrm{g}^{-1}$ at $21 \pm 2{ }^{\circ} \mathrm{C}$ and $\mathrm{pH} 5.0$, higher than that of other biosorbents used to remove lead from water. The use of active biomass was not feasible for the removal of lead due to precipitation of the metal and cell growth was inhibited by concentrations of free metal ions in excess of $0.5 \mathrm{mg} \mathrm{L}^{-1}$. In contrast, inactive cells showed a high capacity for absorbtion of $\mathrm{Pb}^{2+}$ from aqueous solution and equilibrium was reached quickly. Some of the most important applications of microalgae for the biosorption of metals are outlined in Table 2.

\section{Conclusion}

Based on data obtained in a number of studies, there is clear potential for the use of macroalgae and microalgae for the bioremediation of metals. In addition, there is somewhat of an advantage of microalgae over macroalgae due to the ease of collection, preparation and testing of the former. However, further studies of metal biosorption by algae are needed in order to obtain specific relationships correlating the affinities of algae for certain metals with ecological, physiological, biochemical and molecular parameters.

\section{Acknowledgements}

The authors thank the CNPq, CAPES, FAPERGS and FAPESP for funding and fellowship support.

\section{References}

Adhiya J, Cai X, Sayre RT, Traina SJ 2002. Binding of aqueous cadmium by the lyophilized biomass of Chlamydomonas reinhardtii. Colloids Surf A: Physicochem Eng Asp 210: 
$1-11$.

Anastasakis K, Ross AB, Jones JM 2011. Pyrolysis behaviour of the main carbohydrates of brown macro-algae. Fuel 90: 598-607.

Apel K, Hirt H 2004. Reactive oxygen species: metabolism, oxidative stress, and signal transduction. Annu Rev Plant Biol 55: 373-399.

Arora A, Saxena S. 2005. Cultivation of Azolla microphylla biomass on secondary-treated Delhi municipal effluents. Biomass Bioenergy 29: 60-64.

Avilés C, Loza-Tavera H, Terry N, Moreno-Sánchez R 2003. Mercury pretreatment selects an enhanced cadmiumaccumulating phenotype in Euglena gracilis. Arch Microbiol 180: 1-10.

Bargagli R, Nelli L, Ancora S, Focardi S 1996. Elevated cadmium accumulation in marine organisms from Terranova Bay (Antarctica). Polar Biol 16: 513-520.

Bashan LE, Bashan Y 2010. Immobilized microalgae for removing pollutants: review of practical aspects. Bioresour Technol 101: 1611-1627.

Baumann HA, Morrison L, Stengel DB 2009. Metal accumulation and toxicity measured by PAM Chlorophyll fluorescence in seven species of marine macroalgae. Ecotox Environ Safe 72: 1063-1075.

Bayramoğlu G, Tuzun I, Celik G, Yilmaz M, Arica MY 2006. Biosorption of mercury (II), cadmium (II) and lead (II) ions from aqueous system by microalgae Chlamydomonas reinhardtii immobilized in alginate beads. Int J Miner Process 81: 35-43

Beyersmann D, Hartwig A 2008. Carcinogenic metal compounds: Recent insight intomolecular and cellular mechanisms. Arch Toxicol 82: 493-512.

Blunt JW, Copp BR, Munro MHG, Northcote PT, Prinsep MR 2005. Marine natural products. Nat Prod Rep 22: 1561.

Boobathy S, Soundarapandian P, Prithivraj M, Gunasundari V 2010. Biochemical characterization of protein isolated from seaweed. Gracilaria edulis. Curr Res J Biol Sci 2: 35-37.

Briens C, Piskorz J, Berruti F 2008. Biomass valorization for fuel and chemicals production - a review. Int J Chem React Eng 6: 1-49.

Brown MR, Miller KA 1992. The ascorbic acid content of eleven species of microalgae used in marine culture. $J$ Appl Phycol 4: 205-215.

Burja AM, Banaigs B, Abou-Mansour E, Burguess JG, Wright PC 2001. Marine cyanobacteria - a profilic source of natural products. Tetrahedron 57: 9347-9377.

Cardozo KHM, Carvalho VM, Pinto E, Colepicolo P 2006. Fragmentation of mycosporine-like amino acids by hydrogen/deuterium exchange and electrospray ionisation tandem mass spectrometry. Rapid Commun Mass Sp 20: 253-258.

Cardozo KHM, Guaratini T, Barros MP, Falcão VR, Tonon AP, Lopes NP, Campos S, Torres MA, Souza AO, Colepicolo
P, Pinto E 2007. Metabolites from algae with economical impact. Comp Biochem Physiol C-Toxicol Pharmacol 146: $60-78$

Cardozo KHM, Vessecchi R, Carvalho VM, Pinto E, Gates PJ, Colepicolo P, Galembeck SE, Lopes NP 2008. A theoretical and mass spectrometry study of the fragmentation of mycosporine-like amino acids. Int $J$ Mass Spectrom 273: 11-19.

Cardozo KHM, Vessecchi R, Galembeck SE, Guaratini T, Gates PJ, Pinto E, Lopes NP, Colepicolo P 2009. A fragmentation study of di-acidic mycosporine-like amino acids in electrospray and nanospray mass spectrometry. $J$ Braz Chem Soc 20: 1625-1631.

Carignan MO, Cardozo KHM, Oliveira-Silva D, Colepicolo P, Carreto JI 2009. Palythine-threonine, a major novel mycosporine-like amino acid (MAA) isolated from the hermatypic coral Pocillopora capitata. J Photochem Photobiol B: Biology 94: 191-200.

Cardwell AJ, Hawker DW, Greenway M 2002. Metal accumulation in aquatic macrophytes from southeast Queensland, Australia. Chemosphere 48: 653-663.

Carrilho ENVM, Nóbrega JA, Gilbert TR 2003. The use of silica-immobilized brown alga (Pilayella littoralis) for metal preconcentration and determination by inductively coupled plasma optical emission spectrometry. Talanta 60: 1131-1140.

Cerniglia CE, Baalen CV, Gibson DT 1980. Metabolism of naphthalene by the cyanobacterium Oscillatoria sp. strain JCM. J Gen Microbiol 116: 485-494.

Cerniglia CE, Gibson DT, Baalen CV 1979. Algal oxidation of aromatic hydrocarbons: formation of 1-naphthol from naphthalene by Agmenellum quadruplicatum, strain PR-6. Biochem Biophys Res Commun 88: 50-58.

Chandini SK, Ganesa P, Bhaskar N 2008. In vitro antioxidant activities of three selected seaweeds of India. Food Chem 107: 707-713.

Chinnasamy S, Bhatnagar A, Hunt RW, Das KC 2010. Microalgae cultivation in a wastewater dominated by carpet mill effluents for biofuel applications. Bioresour Technol 101: 3097-3105.

Chisti Y 2007. Biodiesel from microalgae. Biotechnol Adv 25: 249-306.

Cobbett C, Goldsbrough P 2002. Phytochelatin and metallothioneins: Roles in heavy metal detoxification and homeostasis. Annu Rev Plant Biol 53: 159-182.

Collen J, Pinto E, Pedersen M, Colepicolo P 2003. Induction of oxidative stress in the red macroalga Gracilaria tenuistipitata by pollutant metals. Arch Environ Contam Toxicol 45: 337-342.

Daby D 2006. Coastal pollution and potential biomonitors of metals in Mauritius. Water Air Soil Poll 174: 63-91.

Daka ER, Allen JR, Hawkins SJ 2003. Heavy metal contamination in sediment and biomonitors from sites around the Isle of Man. Mar Pollut Bull 46: 784-791.

Danquah MK, Gladman B, Moheimani N, Forde GM 2009. 
Microalgal growth characteristics and subsequent influence on dewatering efficiency. Chem Eng $J 151$ : 73-78.

Davis TA, Llanes F, Volesky B, Diaz-pulido G, Mccook L, Mucco A 2003. 1H-NMR Study of Na alginates extracted from Sargassum spp. in relation to metal biosorption. Appl Biochem Biotechnol 110: 75-90.

Dawczynski C, Schubert R, Jahreis G 2007. Amino acids, fatty acids, and dietary fibre in edible seaweed products. Food Chem 103: 891-899.

Dhargalkar VK, Verlecar XN 2009. Southern Ocean seaweeds: a resource for exploration in food and drugs. Aquaculture 287: 229-242.

Di Mascio P, Hollnagel HC, Sperança MA, Colepicolo P 1995. Diurnal rhythm of carotenoids in the photosynthetic algae Gonyaulax polyedra. Biol Chem H-S 376: $297-$ 301.

Dönmez G, Aksu Z 2002. Removal of chromium(VI) from saline wastewaters by Dunaliella species. Process Biochem 38 : 751-762.

Falcão VR, Nyvall P, Collen J, Pedersén M, Oliveira MC, Colepicolo P 2010. Molecular characterization of nitrate reductase gene and its expression in the marine red alga Gracilaria tenuistipitata (Rhodophyta). J Appl Phycol 22: 613-622.

Farıas S, Arisnabarreta SP, Vodopivez C, Smichowski P 2002. Levels of essential and potentially toxic trace metals in Antarctic macro algae. Spectrochim Acta Part B 57: 2133-2140.

Favero N, Frigo M G 2002. Biomonitoring of metal availability in the southern basin of the Lagoon of Venice (Italy) by means of macroalgae. Water Air Soil Pollut 140: 231246.

Figueira MM, Volesky B, Ciminelli VST, Roddick FA 2000. Biosorption of metals in brown seaweed biomass. Water Res 34: 196-204.

Garcia J, Green BF, Lundquist T, Mujeriego R, Hernandez-Marine M, Oswald WJ 2009. Long term diurnal variations in contaminant removal in high rate ponds treating urban wastewater. Bioresour Technol 97: 1709-1715.

Gledhill M, Nimmo M, Hill SJ, Brown MT 1997. The toxicity of copper(II) species to marine algae, with particular reference to macroalgae. $J$ Phycol 33: 2-11.

Godos I, Blanco S, García-Encina PA, Becares E, Munoz R 2009. Long-term operation of high rate algal ponds for the bioremediation of piggery wastewaters at high loading rates. Bioresour Technol 100: 4332-4339.

Gosavi K, Sammut J, Gifford S, Jankowski J 2004. Macroalgal biomonitors of trace metal contamination in acid sulfate soil aquaculture ponds. Sci Total Environ 324: 25-39.

Goyal N, Jain SC, Banerjee US 2003. Comparative studies on the microbial adsorption of heavy metals, $A d v$ Environ Res 7: 311-319.

Gressler V, Colepicolo P, Pinto E 2009. Useful strategies for algal volatile analysis. Current Anal Chem 5: 271-292.
Gressler V, Yokoya, NS, Fujii, MT, Colepicolo, P, Mancini, J, Torres, RP, Pinto, E 2010. Lipid, fatty acid, protein, amino acid and ash contents in four Brazilian red algae species. Food Chem 120: 585-590.

Gressler V, Fujii MT, Martins AP, Colepicolo P, ManciniFilhod J, Pinto E 2011. Biochemical composition of two red seaweed species grown on the Brazilian coast. J Sci Food Agric 91: 1687-1692.

Grill E, Winnacker EL, Zenk MH 1985. Phytochelatins: the principal heavy-metal complexing peptides of higher plants. Science 230: 674-676.

Grima EM, Belarbi EH, Fernandez FGA, Medina AR, Chisti Y 2003. Recovery of microalgal biomass and metabolites: process options and economics. Biotechnol Adv 20: 491-515.

Guaratini T, Vessecchi R, Pinto E, Colepicolo P, Lopes NP. 2005. Balance of xanthophylls molecular and quasimolecular ions in electrospray ionization. $J$ Mass Spectrom 40: 963-968

Guaratini T, Lopes NP, Pinto E, Colepicolo P, Gates PJ 2007. Differential ionisation of natural antioxidant polyenes in ESI and NanoESI mass spectrometry. Rapid Comm Mass Sp 21: 3842-3848.

Guaratini T, Cardozo KHM, Pinto E, Colepicolo P 2009. Comparison of diode array and electrochemical detection in the C-30 reverse phase HPLC analysis of algae carotenoids. J Braz Chem Soc 20: 1609-1616.

Guerinot ML 2000. The ZIP family of metal transporters. Biochim Biophys Acta-Biomembr 1465: 190-198.

Hashim MA, Chu KH 2004. Biosorption of cadmium by brown, green and red seaweeds. Chem Eng J 97: 249255.

He M, Wang Z, Tang H 1998. The chemical, toxicological and ecological studies in assessing the heavy metal pollution in Le An river, China. Water Res 32: 510-518.

Hobuss CB, Rosales PF, Venzke D, Souza PO, Gobbi PC, Gouvea LP, Santos MAZ, Pinto E, Jacob-Lopes E, Pereira CM P 2011. Cultivation of algae in photobioreator and obtention of biodiesel. Rev Bras Farmacogn 21: 361-364.

Hollnagel HC, Di Mascio P, Asano CS, Okamoto OK, Stringher CG, Oliveira MC, Colepicolo P 1996. The effect of light on the biosynthesis of $\beta$-carotene and superoxide dismutase activity in the photosynthetic alga Gonyaulax polyedra. Braz J Med Biol Res 29: 105-111.

Howe G, Merchant S 1992. Heavy metal-activated synthesis of peptides in Chlamydomonas reinhardtii. Plant Physiol 98: 127-136.

Inthorn D, Sidtitoon N, Silapanuntakul S, Incharoensakdi A 2002. Sorption of mercury, cadmium and lead by microalgae. Sci Asia 28: 253-261.

John J 2000. A self-sustainable remediation system for acidic mine voids. In: $4^{\text {th }}$ International conference of diffuse pollution p.506-511

Kalyani S, Rao PS, Krishnaiah A 2004. Removal of nickel 
(II) from aqueous solutions using marine macroalgae as the sorbing biomass. Chemosphere 57: 1225-1229.

Kamatou GPP, Zyl RLV, Vuuren SFV, Figueiredo AC, Barroso JG, Pedro LG, Viljoen AM 2008. Seasonal variation in oil composition, oil toxicity and the biological activity of solvent extracts of three South African Salvia species. S Afr J Bot 74: 230-237.

Kapoor A, Viraraghavan T 1995. Fungal biosorption - an alternative treatment option for heavy metal bearing wastewaters: a review. Bioresour Technol 53: 195-206.

Kashman Y, Rudi A 2004. On the biosynthesis of marine isoprenoids. Phytochem Rev 3: 309-323.

Kladi M, Vagias C, Roussis V 2004. Volatile halogenated metabolites from red algae. Phytochem Rev 3: 337-366.

Kong Q-x, Li L, Martinez B, Chen P, Ruan R 2010. Culture of microalgae Chlamydomonas reinhardtii in wastewater for biomass feedstock production. Appl Biochem Biotechnol 160: 9-18.

Kratochvil D, Volesky B 1998. Advances in the biosorption of heavy metals. Trends Biotechnol 16: 291-300.

Kumar D, Gaur JP 2011. Metal biosorption by two cyanobacterial mats in relation to $\mathrm{pH}$, biomass concentration, pretreatment and reuse. Bioresour Technol 102: 2529-2535.

Kumar JIN, Oommen C; Kumar RN 2009. Biosorption of heavy metals from aqueous solution by green marine macroalgae from Okha Port, Gulf of Kutch, India. American-Eurasian J Agric \& Environ Sci 6: 317-323.

Küpper H, Küpper FC, Spiller M 1998. In situ detection of heavy metal substituted chlorophyll in water plants. Photosynth Res 58: 123-133.

Küpper H, Küpper FC, Spiller M 1996. Environmental relevance of heavy metal-substituted chlorophylls using the example of water plants. J Exp Bot 47: 259266.

Kuppusamy V, Jegan JR, Palanivelu K, Velan M 2004. Copper removal from aqueous solution by marine green alga Ulva reticulate. Electron J Biotechnol 7: 61-71.

Leborans GF, Novillo A 1996. Toxicity and bioaccumulation of cadmium in Olisthodiscus luteus (Raphidophyceae). Water Res 30: 57-62.

Lee Y-C, Chang S-P 2011. The biosorption of heavy metals from aqueous solution by Spirogyra and Cladophora filamentous macroalgae. Bioresour Technol 102: 5297-5304.

Leitão MAS, Cardozo KHM, Pinto E, Colepicolo P 2003. PCB-Induced oxidative stress in the unicellular marine dinoflagellate Lingulodinium polyedrum. Arch Environm Contamin Toxicol 45: 59-65.

Lourie E, Patil V, Gjengedal E 2010. Efficient purification of heavy-metal-contaminated water by microalgaeactivated pine bark. Water Air Soil Pollut 210: 493500.

MacFarlane GR, Burchett MD 2001. Photosynthetic pigments and peroxidase activity as indicators of heavy metals stress in grey mangrove, Avicennia marina (Forsk.) Vierh. Mar Pollut Bull 42: 233-240.

Macfie SM, Welbourn PM 2000. The cell wall as a barrier to uptake of metal ions in the unicellular green alga Chlamydomonas reinhardtii (Chlorophyceae). Arch Environ Contam Toxicol 39: 413-419.

Mehta SK, Gaur JP 2001. Characterization and optimization of $\mathrm{Ni}$ and $\mathrm{Cu}$ sorption from aqueous solution by Chlorella vulgaris. Ecol Eng 18: 1-13.

Mehta SK, Tripathi BN, Gaur JP 2002. Enhanced sorption of $\mathrm{Cu}^{2+}$ and $\mathrm{Ni}^{2+}$ by acid-pretreated Chlorella vulgaris from single and binarymetal solutions. J Appl Phycol 14: 267-273.

Mendoza-Cózatl D, Loza-Tavera H, Hernández-Navarro A, Moreno-Sánchez R 2005. Sulfur assimilation and glutathione metabolism under cadmium stress in yeast, protist and plants. FEMS Microbiol Rev 29: 653-671.

Mesko MF, Hartwig CA, Bizzi CA, Pereira JSF, Mello PA, Flores EMM 2011. Sample preparation strategies for bioinorganic analysis by inductively coupled mass spectrometry. Int J Mass Spectrom 307: 123-136

Mesple F, Casellas C, Troussellier M, Bontoux J 1996. Modelling orthophosphate evolution in a high rate algal pond. Ecol Modell 89: 13-21.

Miles CD, Brandle JR, Daniel DJ, Chu-Der O, Schnare PD, Uhlik DJ 1972. Inhibition of PS II in isolated chloroplasts by lead. Plant Physiol 49: 820-825.

Moreno-Garrido I 2008. Microalgae immobilization: current techniques and uses. Bioresour Technol 99: 39493964.

Munoz R, Guieysse B 2006. Algal-bacterial processes for the treatment of hazardous contaminants: a review. Water Res 40: 2799-2815.

Mutanda T, Ramesh D, Karthikeyan S, Kumari S, Anandraj A, Bux F 2011. Bioprospecting for hyper-lipid producing microalgal strains for sustainable biofuel production. Bioresour Technol 102: 57-70

Nagase H, Inthorn D, Oda A, Nishimura J, Kajiwara Y, Park MO, Hirata K, Miyamoto K 2005. Improvement of selective removal of heavy metals in cyanobacteria by $\mathrm{NaOH}$ treatment. J Biosci Bioeng 99: 372-377.

Nies DH 1999. Microbial heavy-metal resistance. Appl Microbiol Biotechnol 51: 730-750.

Ofer R, Yerachmiel A, Shmuel Y 2003. Marine macroalgae as biosorbents for cadmiun and nickel in water. Water Environ Res 75: 246-253.

Okamoto OK, Pinto E, Latorre LR, Bechara EJH, Colepicolo P 2001. Antioxidant modulation in response to metalinduced oxidative stress in algal chloroplasts. Arch Environ Contam Toxicol 40: 18-24.

Olguın EJ 2003. Phycoremediation: key issues for costeffective nutrient removal processes. Biotechnol Adv 22: 81-91.

Olguin EJ, Sanchez G, Mercado G 2004. Cleaner production 
and environmentally sound biotechnology for the prevention of upstream nutrient pollution in the Mexican coast of the Gulf of México. Ocean Coast Manage 47: 641-670.

Oswald WJ, Gotaas HB 1957. Photosynthesis in sewage treatment. Trans Am Soc Civil Eng 122: 73-105.

Park JBK, Craggs RJ, Shilton AN 2011. Wastewater treatment high rate algal ponds for biofuel production. Bioresour Technol 102: 35-42.

Pascucci PR, Kowalak AD 1999. Metal distributions in complexes with Chlorella vulgaris in seawater and wastewater. Water Environ Res 71: 1165-1170.

Pawlik-Skowronska B 2000. Relationships between acidsoluble thiol peptides and accumulated $\mathrm{Pb}$ in the green alga Stichococcus bacillaris. Aquat Toxicol 50: 221-230.

Pawlik-Skowronska B 2002. Correlations between toxic $\mathrm{Pb}$ effects and production of $\mathrm{Pb}$-induced thiol peptides in the microalga Stichococcus bacillaris. Environ Pollut 119: 119-227.

Perales-Vela HV, Peña-Castro JM, Cañizares-Villanueva RO 2006. Heavy metal detoxification in eukaryotic microalgae. Chemosphere 64: 1-10.

Phillips DJH 1995. The chemistries and environmental fates of trace metals and organochlorines in aquatic ecosystems. Mar Pollut Bull 31: 193-200.

Pinto E, Carvalho AP, Morais KHC, Malcata FX, dos Anjos FM, Colepicolo P 2011. Effects of heavy metals and light levels on the biosynthesis of carotenoids and fatty acids in the macroalgae Gracilaria tenuistipitata (var. liui Zhang \& Xia). Rev Bras Farmacogn 21: 349-354.

Pinto E, Sigaud-Kutner TCS, Leitao MAS, Okamoto OK, Morse D, Colepicolo P 2003a. Heavy metal-induced oxidative stress in algae. J Phycol 39: 1008-1018.

Pinto E, Nieuwerburgh LV, Barros MP, Pedersén M, Colepicolo P, Snoeijs P. 2003b. Density-dependent patterns of thiamine and pigments in production in Nitzschia microcephala. Phytochemistry, 63: 155-163.

Pinto G, Pollio A, Previtera L, Temussi L 2002. Biodegradation of phenols by microalgae. Biotechnol Lett 24: 2047 2051.

Pittman JK, Dean AP, Osundeko O 2011. The potential of sustainable algal biofuel production using wastewater resources. Bioresour Technol 102: 17-25

Plaza M, Cifuentes A, Ibanez E 2008. In the search of new functional food ingredients from algae. Trends Food Sci Tech 19: 31-39.

Pradhan S, Singh S, Rai LC 2007. Characterization of various functional groups present in the capsule of Microcystis and study of their role in biosorption of $\mathrm{Fe}, \mathrm{Ni}$ and $\mathrm{Cr}$. Bioresour Technol. 98: 595-601.

Pujari V, Chandra TS, 2000. Statistical optimization of medium components for enhanced riboflavin production by a UVmutant of Eremothecium ashbyii. Process Biochem 36: 31-37.
Rai PK 2008. Heavy-metal pollution in aquatic ecosystems and its phytoremediation using wetland plants: An eco-sustainable approach. Int J Phytorem 10: 133160.

Rai PK 2010. Phytoremediation of heavy metals in a tropical impoundment of industrial region. Environ Monit Assess 165: 529-537

Rajfur M, Klos A, Waclawek M 2010. Sorption properties of algae Spirogyra sp. and their use for determination of heavy metal ions concentrations in surface water. Bioelectrochemistry 80: 81-86

Rajamani S, Siripornadulsil S, Falcao V, Torres MA, Colepicolo P, Sayre R 2007. Phycorremediation of heavy metals Using Transgenic Microalgae. In: León R, Galván Cejudo A, Fernández E. (Eds) Transgenic Microalgae as Green Cell Factories. Book Series: Advances in Experimental Medicine and Biology: 616, 99-107

Rauser WE 1990. Phytochelatins. Annu Rev Biochem 59: 6186.

Rawat I, Kumar RR, Mutanda T, Bux F 2011. Dual role of microalgae: Phycoremediation of domestic wastewater and biomass production for sustainable biofuels production. Appl Energy 88: 3411-3424.

Ribeiro RFL, Magalhães SMS, Barbosa FAR, Nascentes CC, Campos IC, Moraes DC 2010. Evaluation of the potential of microalgae Microcystis novacekii in the removal of $\mathrm{Pb}^{2+}$ from an aqueous medium. $J$ Hazard Mater 179: 947-953.

Robinson NJ 1989. Algal metallothioneins: secondary metabolites and proteins. J Appl Phycol 1: 5-18.

Rocchetta I, Mazzuca M, Conforti V, Ruiz L, Balzaretti V, de Molina MDR 2006. Effect of chromium on the fatty acid composition of two strains of Euglena gracilis. Environ Pollut 141: 353-358.

Runcie JW, Riddle MJ 2004. Metal concentrations in macroalgae from East Antarctica. Mar Pollut Bull 49: 1114-1119.

Salgado SG, Nieto MAQ, Simon MMB 2006. Optimisation of sample treatment for arsenic speciation in alga samples by focussed sonication and ultrafiltration. Talanta 68: 1522-1527.

Salt DE, Blaylock M, Kumar NPBA, Dushenkov V, Ensley BD, Chet I, Raskin I 1995. Phytoremediation: a novel strategy for the removal of toxic metals from the environment using plants. Biotechnology 13: 468474.

Sampedro MA, Blanco A, Llama MJ, Serra JL 1995. Sorption of heavy metals to Phormidium laminosum biomass. Biotechnol Appl Biochem 22: 355-366.

Schiewer S, Patil SB 1997. Modeling the effect of $\mathrm{pH}$ on biosorption of heavy metals by citrus peels. $J$ Hazard Mater 157: 359-362.

Sigaud-Kutner TCS, Pinto E, Okamoto OK, Latorre LR, Colepicolo P 2002. Changes in superoxide dismutase 
activity and photosynthetic pigment content during growth of marine phytoplankters in batch-cultures. Physiol Plantarum 114: 566-572

Singh A, Kumar D, Gaur JP 2007. Copper (II) and lead (II) sorption from aqueous solution by non-living Spirogyra neglecta. Bioresour Technol 98: 3622-3629.

Singh A, Kumar D, Gaur JP 2008. Removal of $\mathrm{Cu}$ (II) and $\mathrm{Pb}$ (II) by Pithophora oedogonia: sorption, desorption and repeated use of the biomass. J Hazard Mater 152: 10111019.

Singh J, Gu S 2010. Commercialization potential of microalgae for biofuels production. Renew Sust Energy Rev 14: 2596-2610.

Singh S, Kate BN, Banerjee UC 2005. Bioactive compounds from cyanobacteria and microalgae: an overview. Crit Rev Biotechnol 25: 73-95.

Singh S, Pradhan S, Rai LC 1998. Comparative assessment of $\mathrm{Fe}^{3+}$ and $\mathrm{Cu}^{2+}$ biosorption by field and laboratorygrown Microcystis. Process Biochem 33: 495-504.

Soares BM, Vieira AA, Lemões JS, Santos CMM, Mesko MF, Primel EG, D'Oca MGM, Duarte FA 2012. Investigation of major and trace element distribution in the extration-transesterification process of fatty acid methyl esters from microalgae Chlorella sp. Bioresour Technol 110: 730-734.

Steffens JC 1990. The heavy metal-binding peptides of plants. Annu Rev Plant Physiol Plant Mol Biol 41: 553-575.

Stengel DB, Macken A, Morrison L, Morley N 2004. Zinc concentrations in marine macroalgae and a lichen from western Ireland in relation to phylogenetic grouping, habitat and morphology. Mar Pollut Bull 48: 902-909.

Stohs SJ, Bagchi D 1995. Oxidative mechanisms in the toxicity of metal ions. Free Radic Biol Med 18: 321-336.

Sunda WG, Huntsman SA 1998. Processes regulating cellular metal accumulation and physiological effects: phytoplankton as model systems. Sci Total Environ 219: 165-181.

Thiele DJ 1992. Metal-regulated transcription in eukaryotes. Nucleic Acids Res 20: 1183-1191.

Thomas AD, Bohumil V, Alfonso M 2003. A review of the biochemistry of heavy metal biosorption by brown algae. Water Res 37: 4311-4330.

Tonon AP, Oliveira MC, Soriano EM, Colepicolo P 2011. Absorption of metals and characterization of chemical elements present in three species of Gracilaria (Gracilariaceae) Greville: a genus of economical. Rev Bras Farmacogn 21: 355-360.

Torres MA, Barros, Marcelo P, Campos SCG, Pinto E, Rajamani S, Sayre RT, Colepicolo P 2008. Biochemical biomarkers in algae and marine pollution: a review. Ecotox Environ Safe 71: 1-15.

Vavilin DV, Ducruet JM, Matorin DN, Venediktov PS, Rubin AB 1998. Membrane lipid peroxidation, cell viability and Photosystem II activity in the green alga Chlorella pyrenoidosa subjected to various stress conditions. $J$ Photochem Photobiol B-Biol 42: 233-239.

Volesky B, Holan, ZR 1995. Biosorption of heavy metals. Biotechnol Progr 11: 235-250.

Wallenstein FM, Couto RP, Amaral AS, Wilkinson M, Neto AI, Rodrigues AS 2009. Baseline metal concentrations in marine algae from São Miguel (Azores) under different ecological conditions - Urban proximity and shallow water hydrothermal activity. Mar Pollut Bull 58: 438-443.

Wang L, Min M, Li Y, Chen P, Chen Y, Liu Y 2010. Cultivation of green algae Chlorella sp. in different wastewaters from municipal wastewater treatment plant. Appl Biochem Biotechnol 162: 1174-1186.

Wijesinghe WAJP, Jeon Y-J 2011. Biological activities and potential cosmeceutical applications of bioactive components from brown seaweeds: a review. Phytochem Rev 10: 431-443.

Yu Q, Matheickal JT, Yin P, Kaewsarn P 1999. Heavy metal uptake capacities of common marine macroalgal biomass. Water Res 33: 1534-1537.

Zandi K, Tajbakhsh S, Nabipour I, Rastian Z, Yousefi F, Sharafian S, Sartavi K 2010. In vitro antitumor activity of Gracilaria corticata (a red alga) against jurkat and molt-4 human cancer cell lines. Afr J Biotechnol 9: 6787-6790.

Zhang C, O'Connor P 2005. Comparison between heavy metal concentrations in sediments analysed by two methods: Analyses on detection limits and data quality. Appl Geochem 20: 1737-1745.

Zulkali MMD, Ahmad AL, Norulakmal NH 2006. Oryza sativa L. husk as heavy metal adsorbent: optimization with lead as model solution. Bioresour Technol 97: 21-25.

\section{*Correspondence}

Márcia F. Mesko

Laboratório de Controle de Contaminantes em Biomateriais, Centro de Ciências Químicas, Farmacêuticas e de Alimentos, Universidade Federal de Pelotas

Campus Capão do Leão, Caixa Postal 354, 96010-900

Pelotas-RS, Brazil

marcia.mesko@pq.cnpq.br

Tel: +555332757387

Fax: +55 5332757354 